\title{
Interactions between Arenicola marina and Zostera noltii on a tidal flat in the Wadden Sea
}

\author{
Catharina J. M. Philippart* \\ Agricultural University Wageningen, Dept of Nature Conservation, PO Box 8080, 6700 DD Wageningen, The Netherlands \\ and \\ DLO-Institute for Forestry and Nature Research, Dept of Aquatic Ecology, PO Box 167, 1790 AD Den Burg, The Netherlands
}

\begin{abstract}
On the tidal flats off Terschelling in the Dutch Wadden Sea the seagrass Zostera noltii Hornem. and adult lugworms Arenicola marina L. show strictly separate distributions with an abrupt border between the 2 communities. Since seagrass and lugworms do not show different limitations regarding sediment type and emersion period, the border must be the result of other environmental factors or plant-animal interactions. Transplantation experiments on the tidal flats showed that the seagrass was quite capable of growing on the lugworm tidal flat when worms were absent. However, the seagrass density and biomass were severely influenced in the presence of lugworms, most probably due to the worms' sediment-reworking activities. Lugworms quickly disappeared from the experimental sites on the seagrass tidal flat, irrespective of the actual presence of seagrass. A local survey of the seagrass area showed that funnel formation by lugworms to sufficient depth was restricted by a dense clay layer under the sediment surface, a remnant of a former salt marsh. These results indicate that an increase of lugworm densities in the Dutch Wadden Sea may have contributed to the decrease of the area covered by $Z$. noltii on the tidal flats off Terschelling over the last $20 \mathrm{yr}$.
\end{abstract}

KEY WORDS: Zostera noltii Arenicola marina Bioturbation - Interspecific interactions - Wadden Sea

\section{INTRODUCTION}

The seagrass Zostera noltii Hornem. has become rare in the Dutch Wadden Sea (Den Hartog \& Polderman 1975, C. J. M. Philippart \& K. S. Dijkema unpubl.). Throughout the Wadden Sea, this seagrass species can be found to coexist with adult lugworms Arenicola marina L. (Asmus \& Asmus 1985, Michaelis 1987, Reise et al. 1989). However, the characteristic faecal castings of the lugworms are absent in the $Z$. noltii community on the tidal flat south of the Dutch island of Terschelling. This seagrass stand extends several hundred meters from a dike to an area with a high density of lugworms (ca 60 ind. $\mathrm{m}^{-1}$ ), which is completely devoid of seagrass (Philippart \& Dijkema unpubl.). The change from the seagrass community to that of the lugworms is not gradual but abrupt. This sharp border could be the result of different environmental prefer-

- Present address: Netherlands Institute for Sea Research, PO Box 59, 1790 AB Den Burg, Texel, The Netherlands ences or limitations of seagrass and lugworms, or be due to interactions between the species.

The distribution of intertidal benthic organisms is often related to sediment composition and emersion period (Dankers \& Beukema 1983, Dijkema 1991). The seagrass Zostera noltii occurs on all sediment types of the Wadden Sea, but shows a preference for sediments with a silt content over 5\% (Philippart et al. 1992). It occurs over the entire tidal range in tidal flats of the Wadden Sea, but the optimal emersion period differs for different locations. The optimal emersion period ranges from less than $50 \%$ in the area east of the island of Fanø, the most northerly part of the Wadden Sea, to more than $67 \%$ south of the Eiderstedt peninsula in the German Bight. Near the island of Terschelling, the optimal emersion period for $Z$. noltii is around $50 \%$ of the tidal period (Philippart et al. 1992). The lugworm Arenicola marina also occurs within a broad range of sediment types, with highest densities at silt contents of 2 to $12 \%$ (Beukema \& de Vlas 1979). In the Dutch Wadden Sea, adult lugworms occur in the littoral zone 
between $1.9 \mathrm{~m}$ below and $0.4 \mathrm{~m}$ above the Mean Tidal Level (MTL). Highest densities were found between $-0.7 \mathrm{~m}$ and +0.1 m MTL (Beukema \& de Vlas 1979 Dankers \& Beukema 1983), which roughly corresponds to an emersion period between 25 and $50 \%$. At the study site on the tidal flats of Terschelling, the top layer of the sediment consists of sand with a silt content of less than 5\% (Dijkema et al. 1989) and the emersion period varies between 25 and $75 \%$ (Philippart \& Dijkema unpubl.). The abrupt border between seagrass and lugworms can therefore not be explained by different preferences for sediment type or emersion period, because these factors lie well within the suitable ranges of both seagrass and lugworm habitats. It must be the result of other environmental factors or of a plant-animal interaction.

Dense seagrass stands can possibly hamper bioturbation of lugworms when established rhizome mats restrict funnel formation. In addition, dense seagrass stands shade the sediment surface and decrease the growth of microalgae on tidal flats, and thus can reduce the available food supply (Reise 1992) for lugworms which feed on microphytobenthos (Rijken 1979). However, the seagrass on the tidal flats of Terschelling does not have a dense rhizome mat and it covers the sediment completely only for a short period of the year (Philippart unpubl.). Therefore, it is unlikely that lugworms are restricted by the actual presence of seagrass on the seagrass tidal flat.

Lugworms are known to affect the density and settlement of species inhabiting the tidal flats of the Wadden Sea, e.g. the tube-building polychaete Pygospio elegans (Reise 1985), the amphipod Corophium volutator (Flach 1992a) and juveniles of various worm and bivalve species (Flach 1992b). Reise (1985) found that Zostera noltii can invade and settle in a lugworm tidal flat from which the lugworms have been removed. This indicates that lugworms can restrict expansion of seagrass stands. The restriction is most probably caused by the effect of sediment reworking during feeding of the lugworms. Adult lugworms with a density of 85 ind. $\mathrm{m}^{-2}$ rework sediment equivalent to a layer of $33 \mathrm{~cm} \mathrm{yr}^{-1}$ (Cadée 1976). This rate of turnover is likely to affect seagrass growth and survival due to burial of plants

Although the area of the seagrass stand under consideration decreased by almost $30 \%$ within the last 20 yr (Philippart \& Dijkema unpubl.), the border has seemed more or less stable during the last 5 yr (pers. obs.). If the interaction between lugworms and seagrass is the main structuring force for the observed distribution patterns, there has to be at least 1 additional environmental variable which restricts the expansion of lugworms towards the seagrass tidal flats. Earlier investigations on the tidal flats of Terschelling re- vealed the presence of a layer of dense clay below the sandy surface layer, a remnant of a former salt marsh. This layer may restrict the bioturbation by the adult lugworms, and in this way protect the seagrass community (Philippart \& Dijkema unpubl.)

The present study analyses the results of transplantation experiments and a survey. The transplantation experiments were carried out to examine if the strictly separate distribution of seagrass and lugworms on the tidal flats off Terschelling was caused by (1) a mutual interference of seagrass and lugworms, or (2) a restriction by other environmental factors. An additional survey was carried out to examine if the local distributions of seagrass and lugworms were related to the depth of the dense clay layer.

\section{METHODS}

Transplantation experiments. The transplantation experiments commenced in the last week of April 1990 , at the start of the seagrass growing season. Two experimental plots, $50 \mathrm{~m}$ apart, were chosen on the tidal flats off Terschelling. One plot was located on the seagrass tidal flat and the other on the lugworm tidal flat (Fig. 1). Each plot contained 9 experimental transplantation sites, circles with a diameter of $60 \mathrm{~cm}$. At the start of the experiment, the upper layer of sediment $(5 \mathrm{~cm})$ was removed from all sites with a shovel and cleared of seagrass. Rhizomes of Zostera noltii generally do not occur deeper than $5 \mathrm{~cm}$ in the sediment on the tidal flats off Terschelling (pers. obs.).

On the seagrass tidal flat (S), 3 treatments were randomly distributed over 9 sites, i.e. 3 replicates per treatment. In the $\mathrm{S}_{1}$ sites, the cleared sediment was shovelled back and adult lugworms were added. Lugworms were collected on the lugworm tidal flat and transplanted with their heads down into small manmade holes in the experimental sites. Based on a mean density of 56 faecal castings $\mathrm{m}^{-2}$ in the experimental plot on the lugworm tidal flat, 16 adult lugworms were added into each site of $0.28 \mathrm{~m}^{2}$. In 3 other sites on the seagrass tidal flat, the $S_{s}$ sites, gauze with a mesh width of $1 \mathrm{~mm}$ was placed at the bottom before refilling with sediment. Seagrass shoots were collected in close proximity to the experimental plot on the seagrass tidal flat and transplanted into these sites at the same density. This density was more or less equal to that of the removed seagrass community, i.e. ca 1000 shoots $\mathrm{m}^{-2}$. Adult lugworms and seagrass were also transplanted at natural densities into the remaining 3 sites on the seagrass tidal flat, the $S_{s l}$ sites, after the sediment was shovelled back into the holes. As in the other sites, plants were collected from the seagrass tidal flat and lugworms from the lugworm tidal flat. 


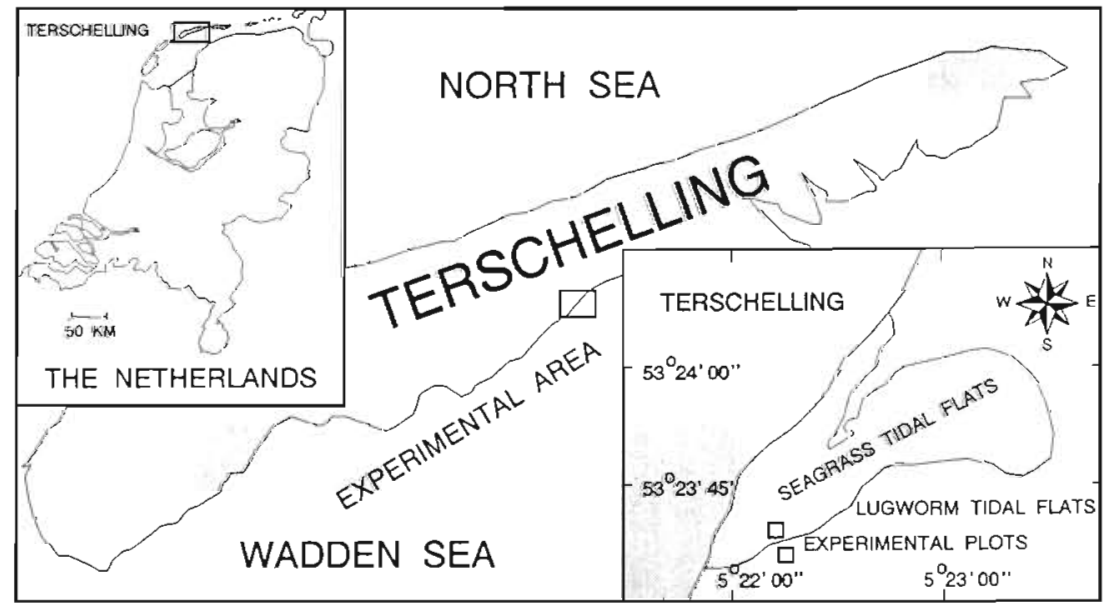

Fig. 1. Location of the experimental plots on the tidal flats off Terschelling. The Netherlands

On the lugworm tidal flat (L), the same 3 treatments as on the seagrass tidal flat were randomly distributed over 9 sites. Sediment was shovelled back in $3 \mathrm{~L}_{1}$ sites. The $\mathrm{L}_{s}$ sites on the lugworm tidal flat were treated in the same way as the $S_{\mathrm{s}}$ sites on the seagrass tidal flat. The small-meshed gauze was meant to protect the seagrass transplants against undermining lugworm bioturbation. Since the gauze was not expected to have additional effects on seagrass, no wide-meshed gauze was used for the controls. Seagrass was transplanted at natural densities into the remaining 3 sites on the lugworm tidal flat, the $L_{s}$ sites, after the sediment was shovelled back into the holes. The seagrass originated from the seagrass tidal flats. No extra lugworms were added to the $\mathrm{L}_{\mathrm{l}}$ and $\mathrm{L}_{\mathrm{sl}}$ sites, because they already contained a natural density of lugworms beneath the upper $5 \mathrm{~cm}$ layer of the sediment.

The experimental sites were cleared after 6 wk lon 6 June). The lugworms and seagrass plants were collected by stratified sieving. The upper $5 \mathrm{~cm}$ layer of sediment was washed through a $1 \mathrm{~mm}$ sieve, and all seagrass material was collected. Dead seagrass material and loose roots were removed and the number of live shoots was determined. The biomass (AFDW) of the seagrass was determined as the difference between dry weight $\left(24 \mathrm{~h}\right.$ at $\left.105^{\circ} \mathrm{C}\right)$ and ash weight $(2 \mathrm{~h}$ at $550^{\circ} \mathrm{C}$ ). The rest of the sediment was removed down to a depth of 0.3 to $0.5 \mathrm{~m}$, which is sufficiently deep to sample all lugworms present (Beukema \& de Vlas 1979). This material was washed through a $2 \mathrm{~mm}$ sieve. The lugworms were stored in $5 \%$ formalin. The seagrass was frozen at $-20^{\circ} \mathrm{C}$ until further handling. The number of lugworms in each sample was counted. The biomass (AFDW) of the lugworms was determined as the difference between dry weight $\left(2\right.$ to $3 \mathrm{~d}$ at $60^{\circ} \mathrm{C}$ ) and the ash weight $\left(2 \mathrm{~h}\right.$ at $600^{\circ} \mathrm{C}$ ).
Hypothesis A states that lugworms are restricted on seagrass tidal flats by other environmental factors than the actual presence of seagrass. This was examined by comparing the abundance of lugworms in the sites without seagrass on the seagrass tidal flat $\left(S_{1}\right.$ sites) to that in the control sites without seagrass on the lugworm tidal flat ( $\mathrm{L}_{1}$ sites). If the lugworms were affected by other environmental factors than by the seagrass itself, their abundance would be lower in the $S_{1}$ sites than in the $\mathrm{L}_{\mathrm{l}}$ sites at the end of the experiment.

Hypothesis B states that seagrass is restricted on lugworm tidal flats by other environmental factors than the actual presence of lugworms. This was examined by comparing the development of the seagrass transplants in the sites without lugworms on the lugworm tidal flat $\left(\mathrm{L}_{\mathrm{s}}\right.$ sites) to that in the control sites without lugworms on the seagrass tidal flat $\left(\mathrm{S}_{\mathrm{s}}\right.$ sites). If the seagrass on the lugworm tidal flat was affected by other environmental factors than the lugworms, its abundance would be lower in the $L_{s}$ sites than in the $S_{5}$ sites at the end of the experiment.

Hypothesis $\mathrm{C}$ states that lugworms are restricted on seagrass tidal flats by the actual presence of seagrass. This was examined by comparing the abundance of the lugworms in the sites on the seagrass tidal flats with seagrass $\left(S_{s l}\right.$ sites) and the control sites without seagrass $\left(\mathrm{S}_{1}\right.$ sites). If the seagrass restricted the presence of lugworms, the abundance of lugworms would be lower in the $S_{s l}$ than in the $S_{1}$ sites at the end of the experiment.

Hypothesis D states that seagrass is restricted on lugworm tidal flats by the actual presence of lugworms. This hypothesis was examined by comparing the development of the seagrass in the sites on the lugworm tidal flats with lugworms $\left(\mathrm{L}_{\mathrm{sl}}\right.$ sites) and the control sites without lugworms ( $\mathrm{L}_{\mathrm{s}}$ sites). If the lugworms restricted the presence of seagrass, the abundance of seagrass would be lower in the $\mathrm{L}_{\mathrm{sl}}$ than in the $\mathrm{L}_{\mathrm{s}}$ sites at the end of the experiment.

Prior to statistical analysis, the data were squareroot transformed to approach normality and homogeneity of variance. Analysis of variance was used to examine the significance of the effects of habitat, treatment and their interaction on the numbers and biomass of seagrass and lugworms. A priori (nonorthogonal) multiple comparisons were made to examine hypotheses A, B, C and D (Sokal \& Rohlf 1981). 
The significance level was corrected by the Bonferroni approach, i.e. $p \leq 0.0125(=0.05 / 4)$.

Survey. The survey was done on 28 June 1990. Four parallel transects, $10 \mathrm{~m}$ apart and located perpendicular to the borderline between the seagrass and the lugworm tidal flat, were sampled every $10 \mathrm{~m}$ with square frames $\left(25 \times 25 \mathrm{~cm}^{2}\right)$. The coverage of seagrass shoots, expressed as a percentage, was estimated within each frame. Firstly, the character of the sediment was assessed by coring up to a depth of $50 \mathrm{~cm}$ in the centre of the frame by means of a perspex core with a diameter of $5 \mathrm{~cm}$. If dense clay was present in the core, the thickness of the sand layer on top of the clay layer was measured. Secondly, the sediment above the clay within the entire frame was sieved up to a maximum depth of $50 \mathrm{~cm}$ in a sieve with a mesh width of $1 \mathrm{~mm}$. The clay layer itself was carefully broken up and checked for the presence of lugworms. All lugworms up to a depth of $50 \mathrm{~cm}$ were collected and stored in $5 \%$ formalin until further handling. The lugworms were divided into 2 length groups, $<5 \mathrm{~cm}$ and $\geq 5 \mathrm{~cm}$. The number of lugworms in each group was counted. Relationships between seagrass coverage, lugworm density and the depth of the clay layer were tested by means of chi-square tests (Elliot 1983).

\section{RESULTS}

\section{Transplantation experiments}

The number and biomass of seagrass and lugworms showed a significant effect of habitat and treatment (Table 1). In addition, the seagrass number and biomass showed a significant interaction between habitat and treatment as the result of a different response to the same treatment on the seagrass and on the lugworm tidal flat (Fig. 2). Although lugworm densities and biomass were generally lower in the seagrass than in the lugworm tidal flats, the response to the different treatments showed a more or less similar pattern (Fig. 2).

The lugworms in the seagrass tidal flat seemed to have been affected by other environmental factors than the actual presence of seagrass (Table 1, hypothesis A). The density and biomass of the lugworms at the end of the experiment were significantly lower in the experimental sites without seagrass on the seagrass tidal flat $\left(\mathrm{S}_{1}\right.$ sites) than in the control sites without

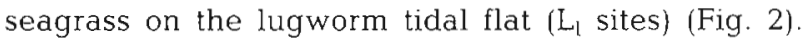
However, these results must be interpreted with caution because the lugworms in the experimental sites on the seagrass tidal flat were more intensively handled than the lugworms in the control sites on the lugworm tidal flat. Some seagrass invaded the sites on the seagrass tidal flat and none the sites on the lugworm tidal flat (Fig. 2), but this difference was not significant (Table 1).

The seagrass in the lugworm tidal flat was not significantly affected at all by other environmental factors than the actual presence of lugworms (Table 1, hypothesis B). The density and biomass of the seagrass at the end of the experiment did not significantly differ in the experimental sites without lugworms on the lugworm tidal flat ( $\mathrm{L}_{\mathrm{s}}$ sites) from those in the control sites without lugworms on the seagrass tidal flat $\left(\mathrm{S}_{\mathrm{s}}\right.$ sites) (Fig. 2). Several lugworms invaded the experimental sites without lugworms. However, lugworm densities and biomass were not significantly different in the $L_{s}$ and the $\mathrm{S}_{5}$ sites (Table 1 ).

Apparently, the lugworms on the seagrass tidal flat were not restricted by the actual presence of seagrass (Table 1 , hypothesis $C$ ). The density and the biomass of the lugworms were not significantly different in the experimental sites on the seagrass tidal flat with seagrass transplants $\left(\mathrm{S}_{\mathrm{sl}}\right.$ sites) compared to the control sites without seagrass $\left(S_{1}\right.$ sites) (Fig. 2). As noticed before, some seagrass recolonized the bare sites on the seagrass tidal flat. However, the seagrass density and biomass were still significantly higher in the $\mathrm{S}_{\mathrm{sl}}$ sites than in the $\mathrm{S}_{1}$ sites (Table 1).

The seagrass on the lugworm tidal flat was obviously affected by the actual presence of the lugworms (Table 1, hypothesis D). The density and the biomass of seagrass transplants on the lugworm tidal flat were significantly lower in the experimental sites without protection against bioturbation by lugworms ( $\mathrm{L}_{\mathrm{si}}$ sites) than in the control sites with protection ( $L_{s}$ sites) (Fig. 2). As was expected, the gauze restricted the 
presence of lugworms. The density and biomass of the lugworms were significantly higher in the unprotected $\mathrm{L}_{\mathrm{sl}}$ sites than in the protected $\mathrm{L}_{\mathrm{s}}$ sites (Table 1).

\section{Survey}

The seagrass density varied between $0 \%$ in the southeastern part of the study area to more than $50 \%$ in the northwestern part, the small $(<5 \mathrm{~cm})$ and large $(\geq 5 \mathrm{~cm}$ ) lugworms occurred mainly in the southeastern part of the study area, and the clay layer was mainly present at less than $24 \mathrm{~cm}$ depth in the northwestern part of the study area (Fig. 3). Lugworms were present only in the sandy sediment, none were found in the dense clay layer. The coverage of seagrass was positively correlated with the density of the small lugworms, and negatively correlated with the density of the large lugworms and the depth of the clay layer under the sediment surface (Table 2). The density of the large lugworms was positively correlated with the depth of the clay layer under the sediment surface, the density of the small lugworms was not (Table 1). No significant relationship was found between the density of the large lugworms and that of the small ones (Table 2).

\section{DISCUSSION}

\section{Effects of lugworms on seagrass}

On the tidal flats off Terschelling, the seagrass Zostera noltii appears to be restricted at its border with the lugworm tidal flat by no other condition than the actual presence of adult lugworms. The immediate effects of bioturbation are coverage of seagrass shoots by faecal castings and burrowing material from funnels. The mean density of the lugworms in the experimental control sites was 68 worms $\mathrm{m}^{-2}$, which are able to rework sediment equivalent to a layer of $26 \mathrm{~cm} \mathrm{yr}^{-1}$ (Cadée 1976). The sediment-reworking activities of the lugworms probably constituted the most direct and important effect on biomass and density of $Z$. noltii on lugworm tidal flats near Terschelling, because the transplanted seagrass shoots disappeared within $6 \mathrm{wk}$ in the unprotected sites on the lugworm tidal flat and were obviously buried.

In addition, bioturbation by lugworms may prevent the survival of seagrass during unfavourable growth periods by the burial of vegetative propagules (rhizomes), or seeds and seedlings as is likewise found for the plant-animal interaction between Salicornia europaea and Corophium volutator (Gerdol \& Hughes 1993). Furthermore, bioturbation could change nutri-
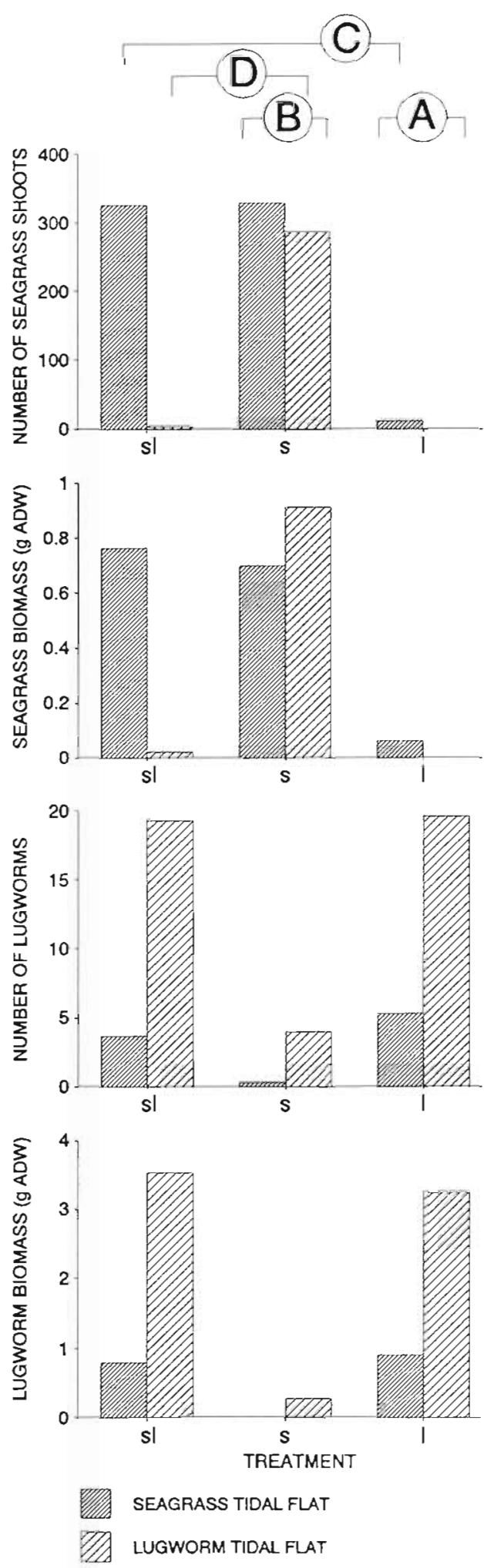

Fig. 2. Zostera noltii and Arenicola marina. Means of numbers and biomass of seagrass and lugworms in the experimental sites containing seagrass and lugworms (sl), seagrass (s) and lugworms (1) on tidal flats off Terschelling on 6 June 1990. Comparisons made between different treatments are indicated 
$x^{2}$
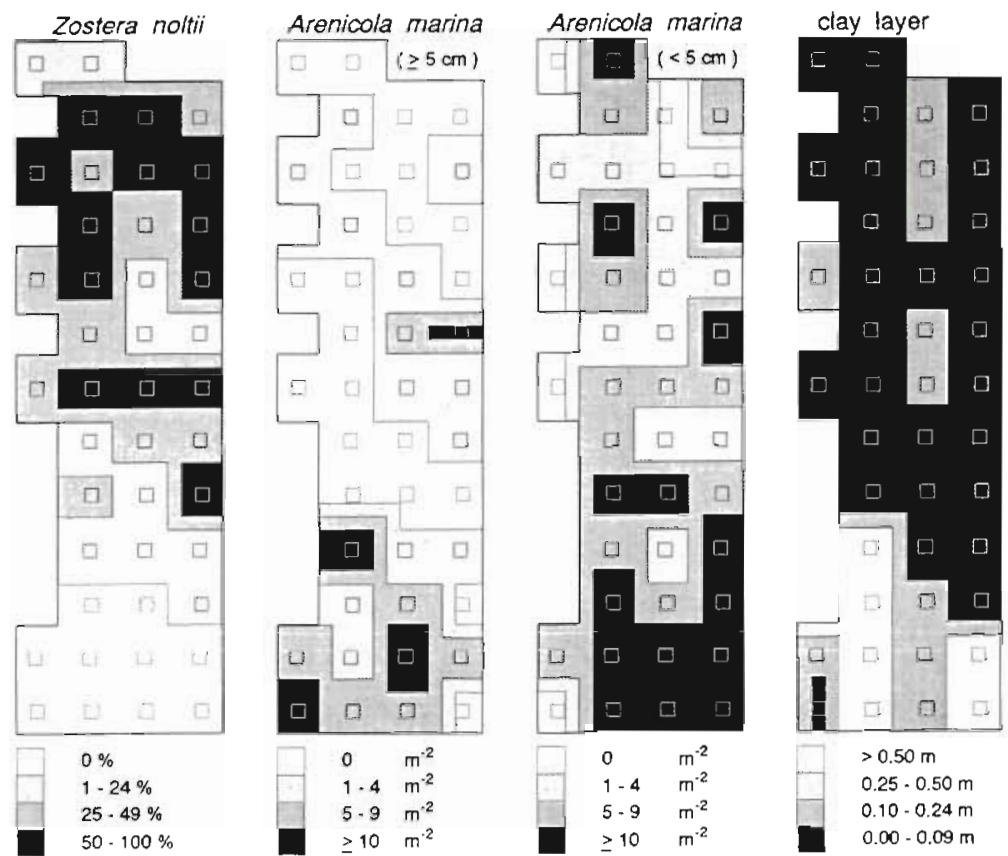

Fig. 3. Zostera noltii and Arenicola marina. Seagrass coverage (\%), density (ind. $\mathrm{m}^{-2}$ ) of lugworms $\geq 5 \mathrm{~cm}$ and $<5 \mathrm{~cm}$, and depth $(\mathrm{m})$ of the clay layer on the surveyed part of the tidal flats off Terschelling on 28 June 1990 may be beneficial as the result of increased nutrient fluxes.

\section{Restrictions for lugworms}

Seagrass could restrict bioturbation by lugworms if the plants established a dense rhizome mat as observed for other seagrasses. However, on the seagrass tidal flat near Terschelling, closed seagrass stands with dense rhizome mats are only found in small parts of the seagrass bed during August/September (Philippart \& Dijkema unpubl.). The transplantation experiments confirm the hypothesis that the absence of Arenicola marina in this seagrass stand does not depend on the actual presence of seagrass. Therefore, the adult lugworms must here be restricted by 1 or more other environmental factors.

Most of the seagrass stand, and in particular the area where a high coverage of Zostera noltii occurred, is located over a layer of clay at a depth of not more than $10 \mathrm{~cm}$. The compactness of this clay layer inhibits funnel formation by lugworms,

ent budgets of seagrass communities by increasing sulphate reduction and nitrate reduction in the sediment (Andersen \& Kristensen 1991). Nutrients may then become either more available to the seagrass or be lost from the seagrass communities as the result of dilution by water transport.

In conclusion, bioturbation can influence seagrass stands in several ways, depending on the density and the activity of the lugworms present. High densities of adult lugworms are expected to have mostly negative effects on seagrass stands as the result of the burial of seagrass material; low densities of juvenile lugworms which need a burrowing depth of at least 10 to $20 \mathrm{~cm}$ (Rijken 1979). Shortened head shafts can make feeding for the lugworm suboptimal if not impossible. In addition, shallow burrows may make lugworms more susceptible to predation by birds, flatfish and crabs Expansion of the lugworm area into the seagrass area seems, therefore, restricted by the presence of the clay under the sediment surface, which inhibits funnel formation at sufficient depth.

These findings are in agreement with the lugworm distribution on the tidal flats east of Hallig Hooge in the German Wadden Sea. Like the tidal flats of Ter-

Table 2. Zostera noltii and Arenicola marina. Significance of the relationships between the coverage (\%) of seagrass, the density (ind $\mathrm{m}^{-2}$ ) of lugworms with length $\geq 5 \mathrm{~cm}$ and $<5 \mathrm{~cm}$, and the depth (m) of the clay layer on the tidal flats off Terschelling on 28 June $1990(n=43 ; \cdot p<0.05, \cdots p<0.01, \cdots p<0.001$, ns: not significant). Seagrass coverage was divided into 4 classes $(0,1-24$, $25-49$ and $\geq 50 \%)$, density of large lugworms into 3 classes $\left(0,1-4\right.$ and $\left.\geq 5 \mathrm{~m}^{-2}\right)$, density of small lugworms into 3 classes $(0,1-9$ and $\left.\geq 10 \mathrm{~m}^{-2}\right)$ and depth of the clay layer into 3 classes $(0-9,10-24$ and $\geq 25 \mathrm{~cm}$ )

\begin{tabular}{|c|c|c|c|c|c|c|}
\hline & & & Correlation & $\chi^{2}$ & df & $\mathrm{p}$ \\
\hline \multirow[t]{3}{*}{ Seagrass $(\%)$} & vs & Lugworms $\geq 5 \mathrm{~cm}$ & - & 22.46 & 6 & * \\
\hline & vs & Lugworms $<5 \mathrm{~cm}$ & + & 14.00 & 6 & $\cdot$ \\
\hline & vs & Depth of clay layer & - & 20.54 & 6 & *. \\
\hline \multirow[t]{2}{*}{ Lugworms $\geq 5 \mathrm{~cm}$} & vs & Lugworms $<5 \mathrm{~cm}$ & None & 3.37 & 4 & $\mathrm{~ns}$ \\
\hline & vs & Depth of clay layer & + & 11.47 & 4 & . \\
\hline Lugworms $<5 \mathrm{~cm}$ & vs & Depth of clay layer & None & 8.19 & 4 & ns \\
\hline
\end{tabular}


schelling, part of Hallig Hooge used to be a salt marsh located on silty sediment. At that time, the area was drained by man-made ditches. After the total area was covered with sand, adult lugworms only settled in those areas where the sand layer was thicker than 10 to $12 \mathrm{~cm}$, i.e. in the former ditches (Plath 1943).

\section{Historical changes}

Reise (1985) found that an experimentally induced increase of lugworm density was followed by gradual sidewards emigration of the lugworms. It was concluded that a strong year class of juveniles probably does not increase the adult density, but would more likely result in the colonization of marginal habitats. From 1970 to 1990, the biomass of Arenicola marina significantly increased on the Balgzand tidal flats in the western part of the Dutch Wadden Sea (Beukema 1992). A simultaneous increase in density of the lugworms on the tidal flats off Terschelling may have resulted in an extension of the area of this lugworm tidal flat in the direction of the seagrass stand. The transplantation experiments show that seagrass is unlikely to survive when invaded by adult lugworms. Decrease of seagrass species in coastal waters of the industrial countries during the last 30 to $50 \mathrm{yr}$ is generally attributed to eutrophication, which causes an increase of periphyton and subsequent decline of the plants (Phillips et al. 1978, Cambridge et al. 1986). In the Dutch Wadden Sea, however, the undermining effect of the lugworms on seagrass may also have played an important role in the observed decrease of Zostera noltii over the last 20 yr. Subsequently, this devastating process may now have been stopped on the tidal flats off Terschelling owing to the presence of remnants of a former salt marsh.

Acknowledgements. The assistance of Corine Hoogenbosch and Koos Zegers is acknowledged in the transplantation experiments, and that of students of the Agricultural University Wageningen in the survey as a part of their study. I am also grateful to Wim van Vierssen for initiating this study, to Jan Beukema, Mardik Leopold, Karsten Reise, Wim Wolff and 3 anonymous referees for their critical comments on the manuscript, to Jaap van der Meer for statistical advice, and to Birthe Bak for linguistic corrections.

\section{LITERATURE CITED}

Andersen, F. Ø., Kristensen, E. (1991). Effects of burrowing macrofauna on organic matter decomposition in coastal marine sediments. Symp. zool. Soc. Lond. 63: 69-88

Asmus, H., Asmus, R. (1985). The importance of grazing food chain for energy flow and production in three intertidal sand bottom communities of the northern Wadden Sea.
Helgoländer Meeresunters. 39: 273-301

Beukema, J. J. (1992). Long-term and recent changes in the benthic macrofauna living on tidal flats in the western part of the Wadden Sea. Neth. Inst. Sea Res. Publ. Ser. 20: $135-141$

Beukema, J. J., de Vlas, J. (1979), Population parameters of the lugworm Arenicola marina, living on tidal flats in the Dutch Wadden Sea. Neth. J. Sea Res. 13: 331-353

Cadée, G. C. (1976). Sediment reworking by Arenicola marina on tidal flats in the Dutch Wadden Sea. Neth. J. Sea Res. 10: $440-460$

Cambridge, M. L., Chiffings, A. W., Brittain, C., Moore, L., McComb, A. J. (1986). The loss of seagrass in Cockburn Sound, Western Australia. II. Possible causes of seagrass decline. Aquat. Bot. 24: 269-285

Dankers, N., Beukema, J. J. (1983). Distributional patterns of macrozoobenthic species in relation to some environmental factors. In: Wolff, W. J. (ed.) Ecology of the Wadden Sea, Vol. 1, Part 4. Balkema, Rotterdam, p. 69-103

Den Hartog, C., Polderman, P. J. G. (1975). Changes in the seagrass populations of the Dutch Waddenzee. Aquat. Bot. 1: $141-147$

Dijkema, K. S. (1991). Towards a habitat map of the Netherlands, German and Danish Wadden Sea. Ocean Shorel. Managem. 16: 1-21

Dijkema, K. S., van Tienen, G., van Beek, J. G. (1989). Habitats of the Netherlands, German and Danish Wadden Sea. Research Institute for Nature Management, Texel

Elliot, J. M. (1983). Statistical analysis of samples of benthic invertebrates. Freshwat. biol. Ass. sci. Publ. 25

Flach, E. C. (1992a). The influence of four macrozoobenthic species on the abundance of the amphipod Corophium volutator on tidal flats of the Wadden Sea. Neth. J. Sea Res. 29: 379-394

Flach, E. C. (1992b). Disturbance of benthic infauna by sediment reworking activities of the lugworm Arenicola marina. Neth. J. Sea Res. 30:81-89

Gerdol, V., Hughes, R. G. (1993). Effect of the amphipod Corophium volutator on the colonisation of mud by the halophyte Salicornia europaea. Mar. Ecol. Prog. Ser. 97 : 61-69

Michaelis, H. (1987). Bestandsaufname des eulitoralen Makrobenthos im Jadebusen in Verbindung mit einer Luftbild-Analyse. Jahresberichte 1986, Forschungs-Stelle Küste 38: 13-97

Philippart, C. J. M., Dijkema, K. S., van der Meer, J. (1992). Wadden Sea seagrasses: where and why? Neth. Inst. Sea Res. Publ. Ser. 20: 177-191

Phillips, G. L., Eminson, D., Moss, B. (1978). A mechanism to account for the decline in progressively eutrophicated waters. Aquat. Bot. 4: 103-126

Plath, M. (1943). Die biologische Bestandsaufname als Verfahren zur Kennzeichnung der Wattsedimente und die Kartierung der nordfriesischen Watten. Westküste 2: 7-46

Reise, K. (1985). Tidal flat ecology; an experimental approach to species interactions. Springer Verlag, Berlin

Reise, K. (1992). Grazing on sediment shores. In: John, D. M., Hawkins, S. J., Price, J. H. (eds.) Plant-animal interactions in the marine benthos. Syst. Ass. Spec. Vol. 46: 133-145

Reise, K., Herre, E., Sturm, M. (1989). Historical changes in the benthos of the Wadden Sea around the island of Sylt in the North Sea. Helgoländer Meeresunters. 43: 417-433

Rijken, M. (1979). Food and food uptake in Arenicola marina. Neth. J. Sea Res. 13: 406-421

Sokal, R. R., Rohlf, F. J. (1981). Biometry, 2nd edn. W. H. Freeman Co., San Francisco 